\section{KAJIAN PERGERAKAN KENDARAAN BELOK KIRI \\ LANGSUNG DAN LURUS LANGSUNG PADA SIMPANG BERSINYAL}

\section{Khoirul Abadi ${ }^{1}$, Imam Muryanto $^{2}$, Hermin Eka Wijayanti ${ }^{3}$}

Staf Pengajar Jurusan Teknik Sipil

Fakultas Teknik - Univ. Muhammadiyah Malang

Kampus III, Jl. Tlogomas No. 246 Telp. (0341) 464318-319 Pes. 130 Fax. (0341) 460435 e-mail: khoirul@umm.ac.id.

Fakultas Teknik - Univ. Muhammadiyah Malang

Kampus III, Jl. Tlogomas No. 246 Telp. (0341) 464318-319 Pes. 130 Fax. (0341) 460435 e-mail: iim_cute2002@yahoo.com

Fakultas Teknik - Univ. Muhammadiyah Malan

Kampus III, Jl. Tlogomas No. 246 Telp. (0341) 464318-319 Pes. 130 Fax. (0341) 460435 e-mail: miiko_bul@yahoo.com

\section{ABSTRACT}

Setting the left turn movement at the intersection of four or three signalized intersections, and the straight movements at three signalized intersections. In any where, there are not provide significant for signalized intersection performance. Changes related legislation does not necessarily contribute positively to the traffic operation. Determination of the application of left turn on red (LTOR) or straight on red (STOR) at an intersection must be preceded by a study, so that the positive affect or negative affect that happened can be known early. The background of this study was motivated the existing conditions arrangement, turn left movements (for intersection of four or three signalized intersections) and straight movements (for three signalized intersections) at some intersection in Malang Raya. In addition, this study was conducted in order to know the effect of setting the movement of vehicles turning left or straight at the intersection. The expected benefits of this study is, that every movement settings, turn left at the intersection of four or three signalized intersections, and also straight movements at three signalized intersections have to go through the review process. Conclusion, shows that the movement of vehicles turning left directly on the intersection of four or three signalized intersections, and the movement of vehicles at the intersection of three straight directly affect the performance of signalized intersections.

Key words: signalized intersection, turn left movement, straight movement, the performance of a signalized intersection.

\section{PENDAHULUAN}

Fenomena adanya pergerakan kendaraan belok kiri pada simpang empat bersinyal ataupun simpang tiga bersinyal, memberi pengaruh cukup signifikan pada kinerja simpang bersinyal, demikian pula dengan pergerakan lurus pada simpang tiga bersinyal. Implementasi peraturan dan perundangan terkait, sementara ini belum difahami oleh sebagian besar masyarakat - pengemudi kendaraan

(bermotor). Peraturan yang dimaksud adalah Peraturan Pemerintah Nomor 43 Tahun 1993 pasal 59 , sedangkan perundangan yang dimaksud adalah Undang Undang Republik Indonesia Nomor 22 Tahun 2009 pasal 112

Pada beberapa simpang bersinyal, pemberlakuan kendaraan belok kiri jalan terus atau belok kiri langsung ketika sinyal/lampu lalu linta menyala merah (left turn on red - LTOR) ataupun kendaraan lurus jalan terus atau lurus langsung ketika sinyal/lampu lalu lintas menyala merah (straight on red - StOR) khusus pada simpang tiga bersinyal, memberikan kinerja simpang bersinyal yang variatif. Fenomena ini akan tampak diantaranya adalah: ada atau tidaknya antrian diantaranya adalah: ada atau tidaknya antriaa
kendaraan, baik kendaraan yang terkena sinyal/ kendaraan, baik kendaraan yang terkena sinyal/,
lampu menyala merah atau yang 'bergerak' lampu menyala merah atau yang 'bergerak' 'bergerak' langsung ketika sinyal/ lampu menyala merah; waktu tempuh melewati simpang (besar kecil tundaan). Hal ini terjadi diduga, karena penetapan - penerapan belok kiri langsung (LTOR) dan atau lurus langsung (StOR) tidak melalui proses studi/kajian ilmiah lebih dulu, atau sekurangkurangnya tidak dilakukan evaluasi terhadap kinerjanya, dalam rangka mengetahui efektifitas penerapan belok kiri langsung (LTOR) dan ataupun lurus langsung (STOR).

Dampak langsung yang bersifat negatif adalah manakala operasional simpang bersinyal menerapkan belok kiri langsung (LTOR) dan atau lurus langsung (STOR) secara tidak 'proporsional', terutama pada jam sibuk adalah menurunnya kinerja simpang bersinyal itu sendiri, diantaranya ditunjukkan adanya antrian kendaraan pada lengan simpang yang cukup panjang, dan apabila ad simpang di dekat simpang tersebut mak menimbulkan overlap. Pada kasus lain, bahu jalan secara terus menerus digunakan untuk pergerakan kendaraan yang belok kiri dan ataupun lurus. Selain daripada itu, arus kendaraan (volume cukup besar) yang mengikuti sinyal 'terganggu' oleh aru kendaraan (volume relatif kecil) yang belok kiri ata yang bergerak lurus.

Mencermatikan fenomena operasional simpang bersinyal tersebut, dapat diformulasikan bahwa kelancaran/kemudahan pergerakan belok kiri langsung dan ataupun lurus langsung, setidaknya dipengaruhi (diantaranya) oleh: (i) leba jalur keluar lengan simpang (ii) lebar jalur masuk lengan simpang (iii) volume arus lalu lintas dar masing-masing lengan (terutama yang berpotensi menimbulkan konflik: crossing, merging dan diverging) (iv) pengaturan/pembatasan pergerakan kendaraan (v) fase sinyal serta (vi) waktu (durasi) sinyal.

Permasalahan pada simpang ini adalah :
Pergerakan arus lalu lintas belok kiri langsung (LTOR) dan ataupun lurus langsung (StOR) mempengaruhi kinerja simpang bersinyal.

Penerapan belok kiri langsung (LTOR) dan ataupun lurus langsung (STOR) yang kurang tepat berpotensi menurunkan kapasitas lengan pada simpang bersinyal, selanjutnya berpotensi menurunkan kinerja simpang.

Volume arus kendaraan baik yang bergerak lurus (pada jalur utama) maupun yang bergerak belok kiri saling berpengaruh terhadap lebar lengan simpang.

Kajian ini bertujuan untuk mengetahui pengaruh penerapan belok kiri langsung (LTOR) pada simpang empat atau simpang tiga bersinyal dan lurus langsung (StOR) pada simpang tiga terhadap kinerja simpang bersinyal.

Hasil kajian ini diharapkan dapat dijadikan model pertimbangan dalam rangka penerapan atau pemberlakuan belok kiri langsung (LTOR) dan lurus langsung (StOR) pada simpang bersinyal, seiring dengan implementasi Undang Undang Republik Indonesia Nomor 22 Tahun 2009.

\section{Sistem Jaringan Jalan}

Sistem jaringan jalan dapat ditetapkan sebaga urutan ruas jalan dan simpul. Ruas jalan berupa potongan atau segmen jalan raya, sedangkan simpul berupa persimpangan, stasiun, dan lain-lain. Sistem jaringan jalan pada suatu daerah dapat dilukiskan, yang mencerminkan satu ruas jalan atau pergerakan membelok di persimpangan dan berakhir pada titik ujung masing-masing yang disebut sebagai simpul. Penghubung pusat zona adalah jenis ruas jalan yang bersifat abstrak yang menghubungkan setiap pusat zona dengan sistem jaringan jalan (Tamin: 1997).

Simpang adalah suatu daerah umum dimana dua ruas jalan atau lebih bergabung atau berpotongan, termasuk fasilitas yang ada disekitar jalan untuk pergerakkan lalulintas dalam daerah tersebut. Simpang merupakan yang terpenting dari jalan perkotaan sebab sebagian besar efisiensi keamanan, kecepatan, biaya operasional dan kapasitas lalulintas tergantung pada perencanaan simpang. Setiap simpang mencakup pergerakkan lalulintas menerus dan lalulintas yang saling 
memotong pada satu atau lebih dari kaki simpang dan mencakup juga pergerakkan perputaran. Pergerakkan lalulintas ini dikendalikan dengan cara bergantung pada jenis simpang. Simpang diklasifikasikan menjadi 2, yaitu simpang bersinyal (terkontrol) dan simpang tak bersinyal (tak terkontrol). (Oglesby dan Hick: 1982)

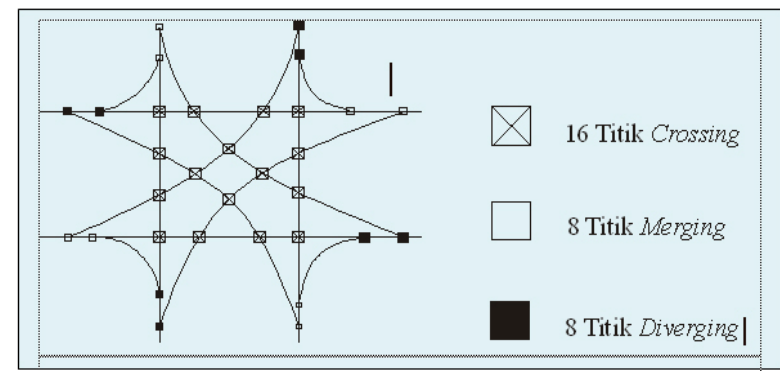

Gambar 1. Titik Konflik pada Simpang Empat Lenga

\section{Simpang Bersinyal}

Direktorat Jenderal Bina Marga (1997) menjelaskan bahwa pada umumnya sinyal lalu lintas dipergunakan untuk satu atau lebih dari alasan lintas dipe

Untuk menghindari kemacetan simpang akibat adanya konflik arus lalu lintas, sehingga terjamin bahwa suatu kapasitas tertentu dapat dipertahankan bahkan selama kondisi lalu lintas jam puncak.

- Untuk memberi kesempatan kepada kendaraan dan/atau pejalan kaki dari jalan

- Simpang (kecil) untuk memotong jalan utama.

- Untuk mengurangi jumlah kecelakaan lalu lintas akibat tabrakan antara kendaraankendaraan dari arah yang berlawanan.

Penggunaan sinyal dengan lampu tiga warna (hijau, kuning, merah) diterapkan untuk memisahkan lintasan dari gerakan-gerakan lalu lintas yang saling bertentangan dalam dimensi waktu. Hal ini adalah keperluan yang mutlak bagi gerakan-gerakan lalu lintas yang datang dari jalanjan yeng saling berpotongan = konlik-kontk jalan yang saling bepologik $=$ konflik utama. Sinyal-sinyal juga dapat digunakan untuk memisahkan gerakan membelok dari lalu lintas melawan, atau untuk memisahkan gerakan lalu lintas membelok dari pejalan kaki yang

38 |Media Teknik Sipil, Volume 9, Nomor 1, Februari 2011: 36 - 49
Warpani (2002), pada simpang empat lengan, titik-titik konflik yang terjadi terdiri dari 16 titik crossing, 8 titik diverging dan 8 titik merging sepert ditunjukan dalam Gambar

menyeberang $=$ konflik-konflik kedua. (Direktora Jenderal Bina Marga: 1997).

\section{Kinerja Simpang Bersinyal}

Prinsip-prinsip utama kinerja simpan ersinyal, sebagaimana dijelaskan Direktora Jenderal Bina Marga (1997), meliputi: geometrik, rus lalu lintas, kapasitas, waktu sinyal, deraja kejenuhan dan tingkat kinerja.

\section{Geometrik}

Satu lengan simpang dapat terdiri dari satu pendekat, yaitu dipisahkan menjadi dua atau lebih sub-pendekat. Hal ini terjadi jika gerakan belok kanan dan/atau belok kiri mendapat sinyal haijau pada fase yang berlainan dengan lalu lintas yang lurus, atau jika dipisahkan secara fisik dengan pulau-pulau lalu lintas dalam pendekat.

Masing-masing pendekat atau sub-pendekat lebar efektif (We) ditetapkan dengan mempertimbangkan denah dari bagian masuk dan ke luar suatu simpang dan distribusi dari gerakan-gerakan membelok.

Arus lalu lintas $(\mathrm{Q})$ untuk setiap gerakan (belok kiri $\mathrm{Q}_{\mathrm{T}}$, lurus $\mathrm{Q}_{\mathrm{ST}}$ dan belok kanan $\mathrm{Q}_{\mathrm{PT}}$ ) dikonversi dari kendaraan per-jam menjad satuan mobil penumpang (smp) per-jam dengan menggunakan ekivalen kendaraan penumpang (emp) untuk masing-masing pendekat terlindung dan terlawan.

- Kapasitas (C) dari suatu pendekat simpan bersinyal dinyatakan dengan formulasi:

Dimana,

$$
\mathrm{C}=\mathrm{S} \times \frac{\mathrm{g}}{\mathrm{c}}(\text { persamaan } 1)
$$

C : kapasitas (smp)

$\mathrm{S}$ :arus jenuh, yaitu arus berangkat rata-rata dari antrian dalam pendekat selama sinyal hijau.

g : Waktu hijau (detik)

c : Waktu siklus, yaitu selang waktu untuk urutan perubahan sinyal yang lengkap

\section{- Waktu sinyal}

Penentuan waktu sinyal untuk keadaan dengan kendali waktu tetap dilakukan berdasarkan metode Webster, untuk meminimumkan tundaan pada suatu simpang. Pertama-tama ditentukan waktu siklus (c) selanjutnya waktu hijau (g) pada masing masing fase (i).

Waktu siklus (detik), ${ }^{\mathrm{c}=}=\frac{(1,5 \times \mathrm{LTT}+5)}{1-\sum \mathrm{FR}_{\text {crit }}}$ (persamaan

Dimana,

LTI : Jumlah waktu hilang per siklus (detik)

FR : Arus dibagi dengan arus jenuh

$\mathrm{FR}_{\text {crit }} \quad$ : Nilai FR tertinggi dari semua pndekat yang berangkat pada suatu fase sinyal

$\Sigma\left(\mathrm{FR}_{\text {crit }}\right):$ Rasio arus simpang $=$ jumlah $\mathrm{FR}_{\text {cri }}$ dari semua fase pada siklus tersebut.

Waktu hijau, $\mathrm{g}_{\mathrm{i}}=\frac{(\mathrm{c}-\mathrm{LTT}) \times \mathrm{FR}_{\text {crit }}}{\sum\left(\mathrm{FR}_{\mathrm{crit}}\right)}($ persamaan 3)

Dimana, $\mathrm{g}_{\mathrm{i}}$ : tampilan waktu hijau pada fase $\mathrm{i}$ (detik)

Derajat kejenuhan (DS), diperoleh dari rumusan:

$$
\mathrm{DS}=\frac{\mathrm{Q}}{\mathrm{C}}=\frac{(\mathrm{Q} \times \mathrm{c})}{(\mathrm{S} \times \mathrm{g})}(\text { persamaan } 4)
$$

\section{Tingkat kinerja.}

Berbagai ukuran tingkat kinerja dapat ditentukan berdasarkan pada arus lalu lintas, derajat kejenuhan dan waktu sinyal, terdiri dari: (i) panjang antrian (ii) angka henti (iii) rasio kendaraan terhenti dan (iv) tundaan, yang terjadi karena dua hal yaitu tundaan lalu lintas (DT) dan tundaan geometrik (DG).

Belok Kiri Langsung Pada Simpang Bersinya Belok kiri langsung adalah hak untuk boleh belok kiri walaupun lampu lalu lintas menunjukkan merah dengan catatan bahwa hak utama pada persimpangan, hak utama penggunaan jalan tetap pada lalu lintas yang mendapatkan lampu hijau dan baru bisa membelok kekiri kalau tidak ada kendaraan yang mempunyai hak. Bila belok kiri langsung dilarang harus dinyatakan dengan lampu filter berbentuk panah merah atau dinyatakan dengan rambu lalu lintas. (http://id.wikipedia.org/ wiki/belok_kiri_boleh_langsung)

Direktorat Jenderal Bina Marga (1997) menjelaskan, bahwa belok kiri langsung diperbolehkan bila ruang jalan yang tersedia mencukupi untuk kendaraan belok kiri melewati antrian lalulintas lurus dari pendekat yang sama, dan dengan aman bersatu dengan lalulintas lurus dari fase lainnya yang masuk ke lengan simpang ang sama.

Undang Undang Republik Indonesia Nomor Jalan pasal 112 (3), mengemukakan: Pada persimpangan Jalan yang dilengkapi Alat Pemberi Isyarat Lalu Lintas, Pengemudi Kendaraan dilarang langsung belok kiri, kecuali ditentukan oleh Rambu Lalu Lintas atau Alat Pemberi Isyarat Lalu Lintas.

\section{METODELOGI}

Simpang bersinyal yang dipilih sebagai lokasi/ obyek kajian, adalah beberapa simpang di Kota Malang:

Simpang empat bersinyal : (i) simpang Jl. Basuki Rahmat - Jl. Semeru - Jl. Kahuripan Basuki Rahmat - Jl. Semeru - Jl. Kahuripan
(ii) simpang Jl. Galunggung - Jl. Tidar - Jl. Bondowoso. 22 Tahun 2009 tentang Lalu Lintas dan Angkutan 

dilakukan, adalah:

- Simpang tiga bersinyal : (i) simpang Jl. MT. Haryono - Jl. Gajayana (ii) Simpang Jl. Letjend Sutoyo - Jl. Sarangan

Kajian kinerja mengacu pada Manual Kapasitas Jalan Indonesia tahun 1997 dengan pokok bahasan simpang bersinyal, yang diterbitkan oleh Direktorat Jendral Bina Marga, Tahapan studi yang

- Kinerja simpang bersinyal kondisi eksisting, dengan menggunakan data fase, siklus sinyal, dan kondisi geometrik eksisting (dengan asumsi diterapkan belok kiri langsung - LTOR dan ataupun lurus langsung - StOR).

- Kinerja simpang bersinyal yang disimulasi dengan cara coba-coba pemberlakuan belok kiri langsung (LTOR) dan ataupun lurus langsung - StOR dengan berbagai variasinya.

Berkaitan dengan data (fase dan siklus sinyal, kondisi geometrik, volume arus lalu lintas merupakan data kondisi eksisting, yang diukur secara langsung di lokasi simpang

\section{HASIL DAN PEMBAHASAN}

Kondisi Eksisting Simpang Bersinyal

- Simpang empat bersinyal

Simpang bersinyal Jl. Basuki Rahmat - Jl. Semeru - Jl. Kahuripan

Kondisi eksisting: geometrik, pergerakan (keempat pendekat diberlakukan belok kir langsung - LTOR) dan volume arus lalulintas jam puncak, disajikan pada gambar 2.

Simpang bersinyal $\mathrm{Jl}$. Galunggung - Jl. Tidar - Jl. Bondowoso

Kondisi eksisting: geometrik, pergerakan (keempat pendekat diberlakukan belok kir langsung - LTOR) dan volume arus lalulintas jam puncak, disajikan pada gambar 3.

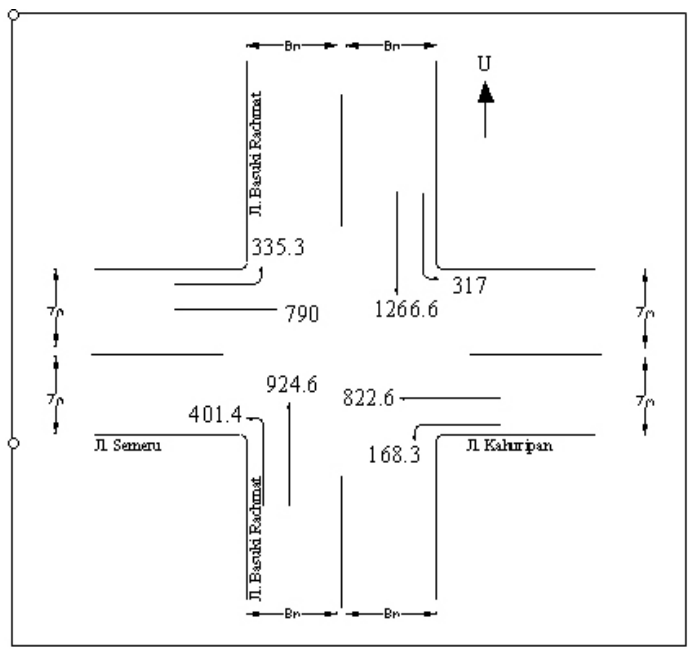

Gambar 2. Pergerakan dan Volume Arus Lalulintas pada Jam Puncak di Simpang Bersinyal Jl. Basuki Rahmat - Jl. Semeru - Jl. Kahuripan (smp/jam)

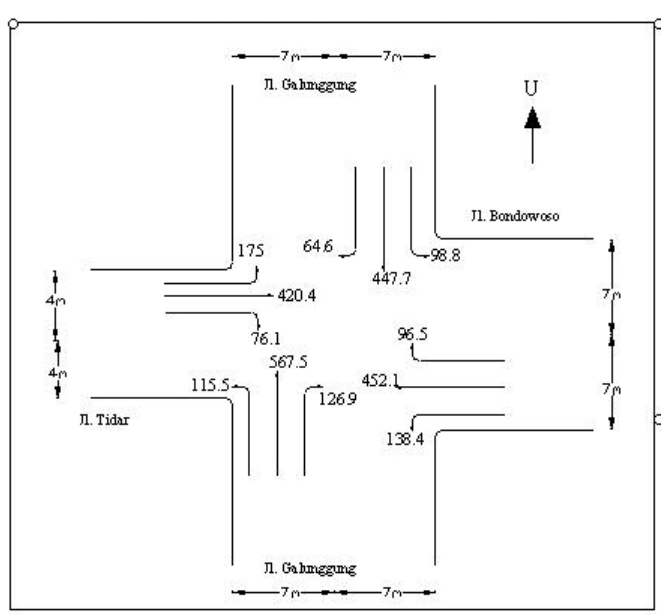

Gambar 3. Pergerakan dan Volume Arus Lalulintas pada Jam Puncak di Simpang Bersinyal Jl. Galunggung - Jl. Tidar -Jl. Bondowoso (smp/jam)

Fase sinyal yang beroperasi pada kedua gambar 4 dan gambar 5, sedangkan durasi sinyal simpang empat bersinyal divisualisasikan pada pada kedua simpang empat bersinyal disajikan pada tabel 1 .

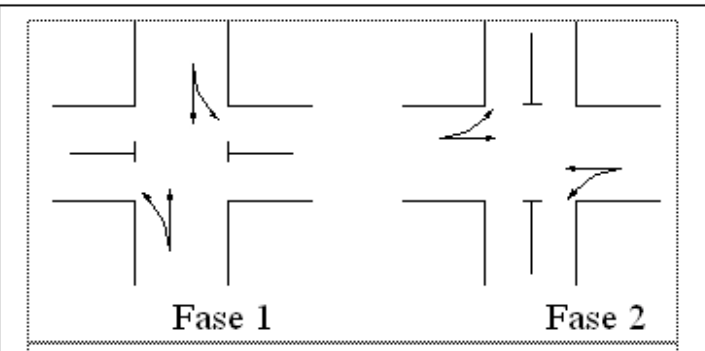

Gambar 4. Fase Sinyal Pada Simpang Bersinyal Jl. Basuki Rahmat - Jl. Semeru - Jl. Kahuripan

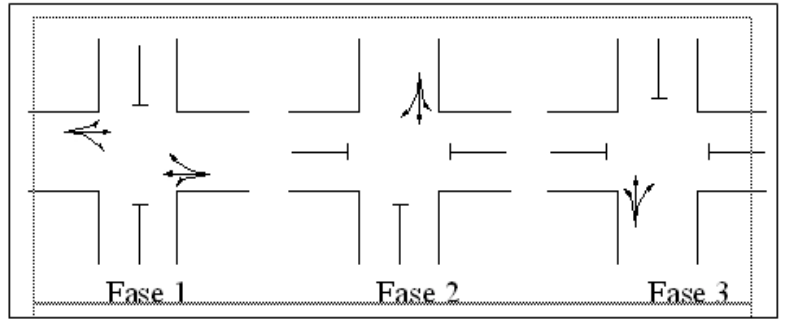

Gambar 5. Fase Sinyal Simpang Bersinyal Jl. Galunggung - Jl. Tidar - Jl. Bondowoso 
Tabel 1. Durasi Sinyal pada Simpang Empat Bersinyal

\begin{tabular}{|c|c|c|c|c|c|}
\hline \multicolumn{3}{|c|}{$\begin{array}{l}\text { Simpang Jl. Basuki Rahmat - Jl. Semeru - } \\
\text { Jl.Kahuripan }\end{array}$} & \multicolumn{3}{|c|}{$\mathrm{Jl}$. Galunggung $-\mathrm{Jl}$. Tidar $-\mathrm{Jl}$. Bondowoso } \\
\hline Pendekat & $\begin{array}{l}\text { Jl. Semeru \& } \\
\text { Jl. Kahuripan }\end{array}$ & $\begin{array}{l}\text { Jl. Basuki Rahmat } \\
\text { (utara) \& (selatan) }\end{array}$ & $\begin{array}{l}\text { Jl. Raya Tidar \& } \\
\text { Jl. Bondowoso }\end{array}$ & $\begin{array}{l}\text { Jl. Galunggung } \\
\text { (utara) }\end{array}$ & $\begin{array}{l}\text { Jl. Galunggung } \\
\text { (selatan) }\end{array}$ \\
\hline Fase & 1 & 2 & 1 & 2 & 3 \\
\hline Merah & $40 "$ & $34 "$ & $48 "$ & $49 "$ & $49 "$ \\
\hline Kuning & 3 "' & 3" & 3", & 3" & 3" \\
\hline Hijau & $22 "$ & 36 " & 18 " & $17 "$ & $17 "$ \\
\hline
\end{tabular}

\section{Simpang tiga bersinyal}

- Simpang bersinyal J1. MT. Haryono - Jl. Gajayana

Kondisi eksisting: geometrik, pergerakan (pada lengan timur dan lengan selatan diberlakukan belok kiri langsung - LTOR, sedangkan pada lengan barat diberlakukan lurus langsung - StOR) dan volume arus lalulintas jam puncak, disajikan pada gambar

Simpang bersinyal Jl. Letjend Sutoyo - Jl. Sarangan

Kondisi eksisting: geometrik, pergerakan (pada lengan selatan dan lengan barat diberlakukan belok kiri langsung - LTOR, sedangkan pada lengan utara kendaraan harus mengikuti lampu sinyal) dan volume arus lalulintas jam puncak, disajikan pada gamba

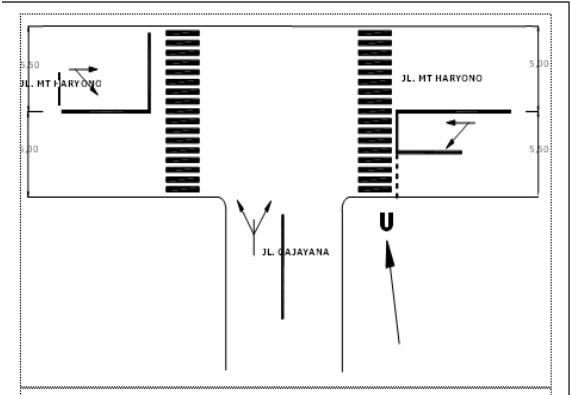

Gambar 6. Kondisi Geometrik, Pergerakan dan Volume Arus Lalulintas Simpang Tiga Bersinyal Jl. MT. Haryono - Jl. Gajayana (smp/jam)

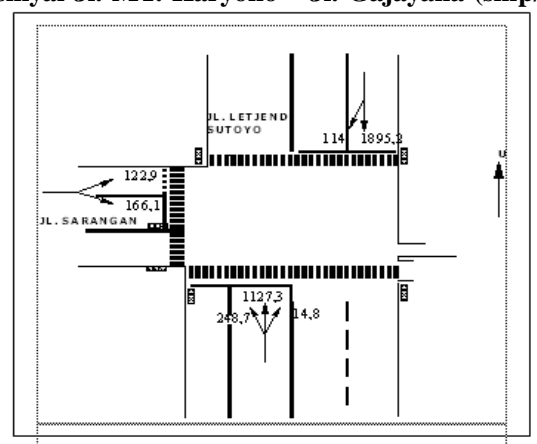

Gambar 7. Kondisi Geometrik, Pergerakan dan Volume Arus Lalulintas Simpang Tiga Bersinyal Jl. Letjend Sutoyo -Jl. Sarangan

42 |Media Teknik Sipil, Volume 9, Nomor 1, Februari 2011: 36 - 49

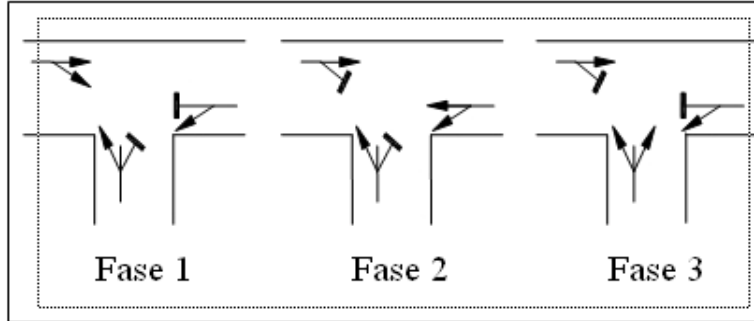

Gambar 8 Fase Sinyal Pada Simpang Tiga Bersinyal Jl. MT. Haryono - Jl. Gajayana

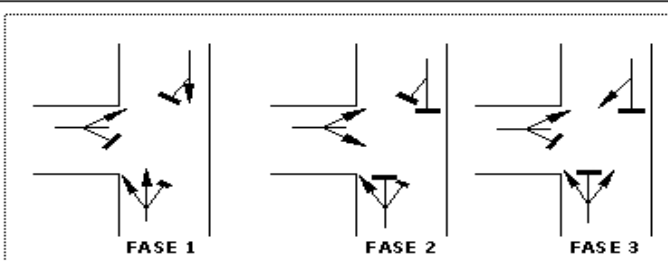

Gambar 9 Fase Sinyal Pada Simpang Tiga Bersinyal Jl. Letjend Sutoyo - Jl. Sarangan

Tabel 2. Durasi Sinyal pada Simpang Tiga Bersinyal

\begin{tabular}{|c|c|c|c|c|c|c|}
\hline \multirow{2}{*}{$\begin{array}{l}\text { Simpang } \\
\text { Pendekat }\end{array}$} & \multicolumn{3}{|c|}{ Jl. MT. Haryono - Jl. Gajayana } & \multicolumn{3}{|c|}{ Jl. Letjend Sutoyo - Jl. Sarangan } \\
\hline & $\begin{array}{l}\text { J1. MT Haryono } \\
\text { (barat) }\end{array}$ & $\begin{array}{l}\text { Jl. MT Haryono } \\
\text { (timur) }\end{array}$ & $\begin{array}{l}\text { Jl. Gajayana } \\
\text { (selatan) }\end{array}$ & $\begin{array}{c}\text { Jl. Letjend Sutoyo } \\
\text { (selatan) }\end{array}$ & $\begin{array}{l}\text { Jl. Sarangan } \\
\text { (barat) }\end{array}$ & $\begin{array}{c}\text { Jl. Letjend } \\
\text { Sutoyo (utara) }\end{array}$ \\
\hline Fase & 1 & 2 & 3 & 1 & 2 & 3 \\
\hline Merah & 53" & $39^{\prime \prime}$ & $58 "$ & $40^{\prime \prime}$ & $53 "$ & $59 "$ \\
\hline Kuning & 3", & 3" & 3" & 3", & 3" & 3" \\
\hline Hijau & 19 " & 33 " & $14 "$ & $33^{\prime \prime}$ & 20 " & $14^{\prime \prime}$ \\
\hline
\end{tabular}

Kinerja Simpang Bersinyal Kondisi Eksisting

Hasil evaluasi kinerja simpang bersinyal dengan tabel 6

kondisi eksisting, dikemukakan pada tabel 3 sampai

Tabel 3. Kinerja Simpang Empat Bersinyal Jl. Basuki Rahmat - Jl. Semeru - Jl. Kahuripan Kondisi Eksisting

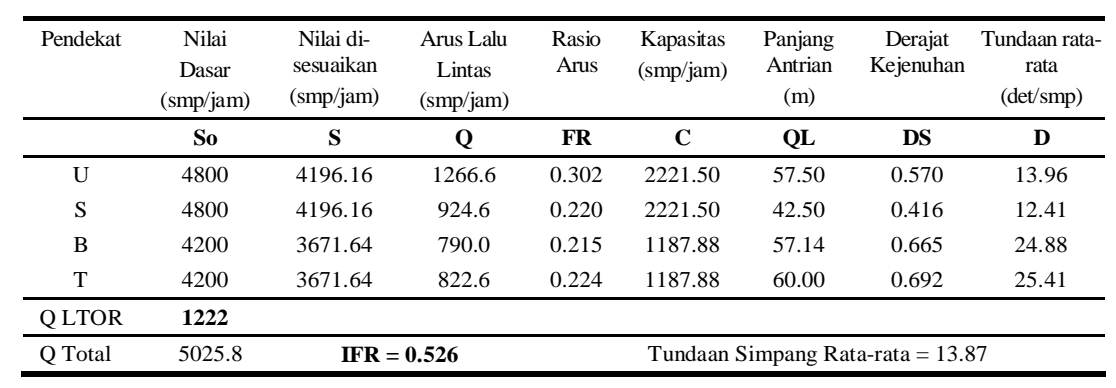

Khoirul Abadi ${ }^{1}$,Imam Muryanto ${ }^{2}$,Hermin Eka Wijayanti ${ }^{3}$, Kajian pergerakan kendaraan belok $\mid 43$ kiri langsung Dan lurus langsung pada simpang bersinyal 
Tabel 4. Kinerja Simpang Empat Bersinyal Jl. Galunggung - Jl. Tidar - Jl. Bondowoso Kondisi Eksisting

\begin{tabular}{|c|c|c|c|c|c|c|c|c|}
\hline Pendekat & $\begin{array}{l}\text { Nilai Dasar } \\
\text { (smp/jam) }\end{array}$ & $\begin{array}{c}\text { Nilai di- } \\
\text { sesuaikan } \\
\text { (smp/jam) }\end{array}$ & $\begin{array}{c}\text { Arus Lalu } \\
\text { Lintas } \\
\text { (smp/jam) }\end{array}$ & $\begin{array}{l}\text { Rasio } \\
\text { Arus }\end{array}$ & $\begin{array}{l}\text { Kapasitas } \\
\text { (smp/jam) }\end{array}$ & $\begin{array}{l}\text { Panjang } \\
\text { Antrian } \\
\text { (m) }\end{array}$ & $\begin{array}{c}\text { Derajat } \\
\text { Kejenuhan }\end{array}$ & $\begin{array}{c}\text { Tundaan rata- } \\
\text { rata } \\
\text { (det/smp) }\end{array}$ \\
\hline & So & $\mathbf{S}$ & $\mathbf{Q}$ & FR & $\mathbf{C}$ & $\mathbf{Q L}$ & DS & D \\
\hline $\mathrm{U}$ & 4200 & 3671.64 & 512.3 & 0.14 & 931.61 & 42.80 & 0.55 & 25.61 \\
\hline $\mathrm{s}$ & 4200 & 3671.64 & 694.4 & 0.19 & 931.61 & 54.29 & 0.75 & 30.47 \\
\hline B & 2880 & 2544.77 & 496.5 & 0.20 & 683.67 & 80.00 & 0.73 & 30.79 \\
\hline $\mathrm{T}$ & 4200 & 3671.64 & 548.6 & 0.15 & 986.41 & 42.86 & 0.56 & 25.11 \\
\hline Q LTOR & 527.7 & & & & & & & \\
\hline Q Total & 2779.5 & \multicolumn{2}{|c|}{ IFR $=0.53$} & \multicolumn{5}{|c|}{ Tundaan Simpang Rata-rata $=22.79$} \\
\hline
\end{tabular}

Tabel 5. Kinerja Simpang Tiga Bersinyal Jl. MT. Haryono - Jl. Gajayana Kondisi Eksisting

\begin{tabular}{|c|c|c|c|c|c|c|c|c|}
\hline Pendekat & $\begin{array}{l}\text { Nilai Dasar } \\
\text { (smp/jam) }\end{array}$ & $\begin{array}{l}\text { Nilai di- } \\
\text { sesuaikan } \\
\text { (smp/jam) }\end{array}$ & $\begin{array}{l}\text { Arus Lalu } \\
\text { Lintas } \\
\text { (smp/jam) }\end{array}$ & $\begin{array}{l}\text { Rasio } \\
\text { Arus }\end{array}$ & $\begin{array}{l}\text { Kapasitas } \\
(\mathrm{smp} / \mathrm{jam})\end{array}$ & $\begin{array}{c}\text { Panjang } \\
\text { Antrian } \\
(\mathrm{m})\end{array}$ & $\begin{array}{c}\text { Derajat } \\
\text { Kejenuh-an }\end{array}$ & $\begin{array}{l}\text { Tundaan } \\
\text { rata-rata } \\
\text { (det/smp) }\end{array}$ \\
\hline & So & $\mathrm{S}$ & $\mathbf{Q}$ & FR & C & $\mathbf{Q L}$ & DS & D \\
\hline B & 2100 & 1969.50 & 483.6 & 0.246 & 473.68 & 183.87 & 1.021 & 141.71 \\
\hline $\mathrm{T}$ & 1800 & 1515.65 & 859.5 & 0.567 & 633.12 & 413.33 & 1.358 & 706.90 \\
\hline $\mathrm{S}$ & 1500 & 1160.03 & 229.8 & 0.198 & 205.57 & 225.24 & 1.118 & 325.18 \\
\hline Q LTOR & 850.6 & & & & & & & \\
\hline Q StOR & 963.5 & & & & & & & \\
\hline Q Total & 3387 & IFR & 0.765 & & Tundac & $\overline{\text { ang } 1}$ & ata $=221,68$ & \\
\hline
\end{tabular}

Tabel 6. Kinerja Simpang Tiga Bersinyal Jl. Letjend Sutoyo - Jl. Sarangan Kondis Eksisting

\begin{tabular}{|c|c|c|c|c|c|c|c|c|}
\hline Pendekat & $\begin{array}{c}\text { Nilai } \\
\text { Dasar } \\
\text { (smp/jam) }\end{array}$ & $\begin{array}{c}\text { Nilai di- } \\
\text { sesuaikan } \\
\text { (smp/jam) }\end{array}$ & $\begin{array}{c}\text { Arus Lalu } \\
\text { Lintas } \\
\text { (smp/jam) }\end{array}$ & $\begin{array}{l}\text { Rasio } \\
\text { Arus }\end{array}$ & $\begin{array}{l}\text { Kapasitas } \\
\text { (smp/jam) }\end{array}$ & $\begin{array}{c}\text { Panjang } \\
\text { Antrian } \\
\text { (m) }\end{array}$ & $\begin{array}{c}\text { Derajat } \\
\text { Kejenuhan }\end{array}$ & $\begin{array}{l}\text { Tundaan } \\
\text { rata-rata } \\
\text { (det/smp) }\end{array}$ \\
\hline & So & $\mathbf{S}$ & $\mathbf{Q}$ & FR & C & QL & DS & D \\
\hline $\mathrm{U}$ & 4200 & 3632.16 & 2009.2 & 0.55 & 1479.77 & 177,14 & 1.358 & 705,78 \\
\hline $\mathrm{s}$ & 4200 & 3472.87 & 1142.1 & 0.33 & 857.50 & 177,14 & 1.332 & 660,53 \\
\hline B & 2250 & 1989.27 & 166.1 & 0.08 & 343.83 & 34,19 & 0.483 & 34,61 \\
\hline Q LTOR & 371.6 & & & & & & & \\
\hline Q StOR & 0 & & & & & & & \\
\hline Q Total & 3689 & \multicolumn{2}{|c|}{ IFR $=0.64$} & \multicolumn{5}{|c|}{ Tundaan simpang rata-rata $=590.46$} \\
\hline
\end{tabular}

Kinerja Simpang Bersinyal Kondisi Simulasi

- Simulasi 1,

Konsekuensi implementasi pergerakan aru kendaraan belok kiri dan atau lurus (simpang tiga) dari semua lengan simpang mengikuti sinyal adalah jumlah arus lalulintas yang ada

pada tiap pendekat cenderung meningkat.

Purus (simpang tiga) dari semua pendekat

simpang, disimulasikan mengikuti sinyal.

44 |Media Teknik Sipil, Volume 9, Nomor 1, Februari 2011:36 -49
Hasil analisa kinerja simpang bersinyal simulasi 1 ini dari keempat simpang bersinya

dikemukakan pada tabel 7 sampai dengan tabel

Tabel 7. Kinerja Simpang Empat Bersinyal Jl. Basuki Rahmat -Jl. Semeru -Jl. Kahuripan Pada Simulasi

\begin{tabular}{|c|c|c|c|c|c|c|c|c|c|}
\hline Pendekat & LTOR & $\begin{array}{c}\text { Nilai Dasar } \\
\text { (smp/jam) }\end{array}$ & $\begin{array}{c}\text { Nilai di- } \\
\text { sesuaikan } \\
\text { (smp/jam) }\end{array}$ & $\begin{array}{l}\text { Arus Lalu } \\
\text { Lintas } \\
\text { (smp/jam) }\end{array}$ & $\begin{array}{l}\text { Rasio } \\
\text { Arus }\end{array}$ & $\begin{array}{l}\text { Kapasitas } \\
\text { (smp/jam) }\end{array}$ & $\begin{array}{c}\text { Panjang } \\
\text { Antrian } \\
\text { (m) }\end{array}$ & $\begin{array}{l}\text { Derajat } \\
\text { Keje- } \\
\text { nuhan }\end{array}$ & $\begin{array}{r}\text { Tundaan } \\
\text { rata-rata } \\
\text { (det/smp) }\end{array}$ \\
\hline & & So & $\mathbf{S}$ & $\mathbf{Q}$ & FR & C & $\mathbf{Q L}$ & DS & D \\
\hline $\mathrm{U}$ & $\mathrm{T}$ & 4800 & 4196.16 & 1583.6 & 0.377 & 2221.50 & 75.00 & 0.713 & 16.46 \\
\hline S & $\mathrm{T}$ & 4800 & 4196.16 & 1326 & 0.316 & 2221.50 & 60.00 & 0.597 & 14.59 \\
\hline B & $\mathrm{T}$ & 4200 & 3671.64 & 1125.3 & 0.306 & 1187.88 & 97.14 & 0.947 & 47.87 \\
\hline $\mathrm{T}$ & $\mathrm{T}$ & 4200 & 3671.64 & 990.9 & 0.270 & 1187.88 & 71.43 & 0.834 & 31.09 \\
\hline Q LTOR & 0 & & & & & & & & \\
\hline Q Total & 5025.8 & & IFR & & & ndaan & ag & $a-$ & \\
\hline
\end{tabular}

Tabel 8. Kinerja Simpang Empat Bersinyal Jl. Galunggung - Jl. Tidar - Jl. Bondowoso Pada Simulasi 1

\begin{tabular}{|c|c|c|c|c|c|c|c|c|c|}
\hline Pendekat & LTOR & $\begin{array}{c}\text { Nilai Dasar } \\
\text { (smp/jam) }\end{array}$ & $\begin{array}{c}\text { Nilai di- } \\
\text { sesuaikan } \\
\text { (smp/jam) }\end{array}$ & $\begin{array}{l}\text { Arus Lalu } \\
\text { Lintas } \\
\text { (smp/jam) }\end{array}$ & $\begin{array}{l}\text { Rasio } \\
\text { Arus }\end{array}$ & $\begin{array}{l}\text { Kapasitas } \\
\text { (smp/jam) }\end{array}$ & $\begin{array}{c}\text { Panjang } \\
\text { Antrian } \\
(\mathrm{m})\end{array}$ & $\begin{array}{c}\text { Derajat } \\
\text { Keje- } \\
\text { nuhan }\end{array}$ & $\begin{array}{c}\text { Tundaan } \\
\text { rata-rata } \\
\text { (det/smp) }\end{array}$ \\
\hline & & So & S & $\mathbf{Q}$ & FR & C & QL & DS & D \\
\hline $\mathrm{U}$ & $\mathrm{T}$ & 4200 & 3671.64 & 611.1 & 0.17 & 931.61 & 48.57 & 0.66 & 27.75 \\
\hline $\mathrm{S}$ & $\mathrm{T}$ & 4200 & 3671.64 & 809.9 & 0.22 & 931.61 & 68.57 & 0.87 & 38.45 \\
\hline B & $\mathrm{T}$ & 2880 & 2517.70 & 671.5 & 0.27 & 676.40 & 155 & 0.99 & 92.24 \\
\hline $\mathrm{T}$ & $\mathrm{T}$ & 4200 & 3671.64 & 687 & 0.19 & 986.41 & 62.86 & 0.70 & 28.11 \\
\hline Q LTOR & 0 & & & & & & & & \\
\hline Q Total & 2779.5 & & IFR & 0.65 & & Tundaan & $\operatorname{ang} R$ & $\mathrm{ata}=4$ & \\
\hline
\end{tabular}

Tabel 9. Kinerja Simpang Tiga Bersinyal Jl. MT. Haryono - Jl. Gajayana Pada Simulasi 1

\begin{tabular}{|c|c|c|c|c|c|c|c|c|c|}
\hline Pendekat & $\begin{array}{l}\text { LTOR/ } \\
\text { StOR }\end{array}$ & $\begin{array}{c}\text { Nilai Dasar } \\
\text { (smp/jam) }\end{array}$ & $\begin{array}{l}\text { Nilai di- } \\
\text { sesuaikan } \\
\text { (smp/jam) }\end{array}$ & $\begin{array}{c}\text { Arus Lalu } \\
\text { Lintas } \\
\text { (smp/jam) }\end{array}$ & $\begin{array}{l}\text { Rasio } \\
\text { Arus }\end{array}$ & $\begin{array}{l}\text { Kapasitas } \\
\text { (smp/jam) }\end{array}$ & $\begin{array}{c}\text { Panjang } \\
\text { Antrian } \\
\text { (m) }\end{array}$ & $\begin{array}{c}\text { Derajat } \\
\text { Keje- } \\
\text { nuhan }\end{array}$ & $\begin{array}{l}\text { Tundaan } \\
\text { rata-rata } \\
\text { (det/smp) }\end{array}$ \\
\hline & & So & 5 & $\mathrm{Q}$ & FR & C & QL & DS & D \\
\hline B & $\mathrm{T}$ & 3300 & 3094,92 & 1447,1 & 0,468 & 744,349 & 225,45 & 1,944 & 1774,10 \\
\hline $\mathrm{T}$ & $\mathrm{T}$ & 00 & 2778,70 & 1116,7 & 0,402 & 1160,72 & 152,57 & 0,962 & 53,97 \\
\hline $\mathrm{S}$ & $\mathrm{T}$ & 2700 & 2239,52 & 823,2 & 0,368 & 396,88 & 275,56 & 2,074 & 2018,31 \\
\hline Q Total & 3387,0 & & IFR $=$ & 835 & Tundaa & 1 simpang ra & ta-rata $=1$ & 266,32 & \\
\hline
\end{tabular}

Khoirul Abadi ${ }^{1}$,Imam Muryanto ${ }^{2}$,Hermin Eka Wijayanti ${ }^{3}$, Kajian pergerakan kendaraan belok $\mathbf{4 5}$ kiri langsung Dan lurus langsung pada simpang bersinyal 
Tabel 10. Kinerja Simpang Tiga Bersinyal Jl. Letjend Sutoyo - Jl. Sarangan Pada Simulasi 1

\begin{tabular}{|c|c|c|c|c|c|c|c|c|c|}
\hline Pendekat & $\begin{array}{l}\text { LTOR/ } \\
\text { StOR }\end{array}$ & $\begin{array}{c}\text { Nilai Dasar } \\
\text { (smp/jam) }\end{array}$ & $\begin{array}{c}\text { Nilai di- } \\
\text { sesuaikan } \\
\text { (smp/jam) }\end{array}$ & $\begin{array}{c}\text { Arus Lalu } \\
\text { Lintas } \\
\text { (smp/jam) }\end{array}$ & $\begin{array}{l}\text { Rasio } \\
\text { Arus }\end{array}$ & $\begin{array}{l}\text { Kapasitas } \\
\text { (smp/jam) }\end{array}$ & $\begin{array}{c}\text { Panjang } \\
\text { Antrian } \\
\text { (m) }\end{array}$ & $\begin{array}{c}\text { Derajat } \\
\text { Keje- } \\
\text { nuhan }\end{array}$ & $\begin{array}{l}\text { Tundaan } \\
\text { rata-rata } \\
\text { (det/smp) }\end{array}$ \\
\hline & & So & $\mathbf{S}$ & $\mathrm{Q}$ & FR & $\mathrm{C}$ & $\mathrm{QL}$ & DS & $\mathrm{D}$ \\
\hline $\mathrm{U}$ & $\mathrm{T}$ & 4200 & 3632,16 & 2009,2 & 0,55 & 1479,77 & 177,14 & 1,358 & 705,78 \\
\hline $\mathrm{s}$ & $\mathrm{T}$ & 5700 & 4713,19 & 1390,8 & 0,30 & 1163,75 & 130,53 & 1,195 & 407,99 \\
\hline B & $\mathrm{T}$ & 4050 & 3580,69 & 289 & 0,08 & 618,89 & 28 & 0,467 & 34,04 \\
\hline Q Total & 3689 & & \multicolumn{2}{|c|}{$\mathrm{IFR}=0,63$} & \multicolumn{5}{|c|}{$\mathrm{rata}=540,88$} \\
\hline
\end{tabular}

\section{- Simulasi Lainnya}

Ada beberapa simulasi dilakukan pada masing-masing simpang. Pergerakan arus kendaraan belok kiri dan atau lurus (simpang tiga) dari semua lengan simpang, disimulasikan secara variatif terhadap operasional sinyal. Salah satu (simulasi $\mathrm{x}$ ) yang terbaik diantara beberapa simulasi pada masing-masing simpang, disajikan pada tabel 11 sampai dengan tabel 14

a Simulasi x pada simpang empat bersinyal

Jl. Basuki Rahmat - Jl. Semeru - Jl.

Kahuripan, yaitu: mensimulasikan bahwa

pergerakan kendaraan dari pendekat utar (Jl. Basuki Rahmat - utara) tidak boleh belok kiri langsung, sedangkan pada ketig pendekatat lainnya disimulasikan belok kiri . dengan pertimbangan: (i) volume arus lalu lintas yang cukup besar pada pendekat utara dibandingkan dengan ketiga lengan lainnya, (ii) potensi terjadinya konflik merging antara kendaraan belok kiri angsung dari pendekat utara (JI. la Rahmat - utara) dengan kendaraan yan bergerak lurus dari pendekat barat ( $\mathrm{J}$ Semeru)

Tabel 11. Kinerja Simpang Empat Bersinyal Jl. Basuki Rahmat - Jl. Semeru - Jl. Kahuripan Pada Simulasi $x$

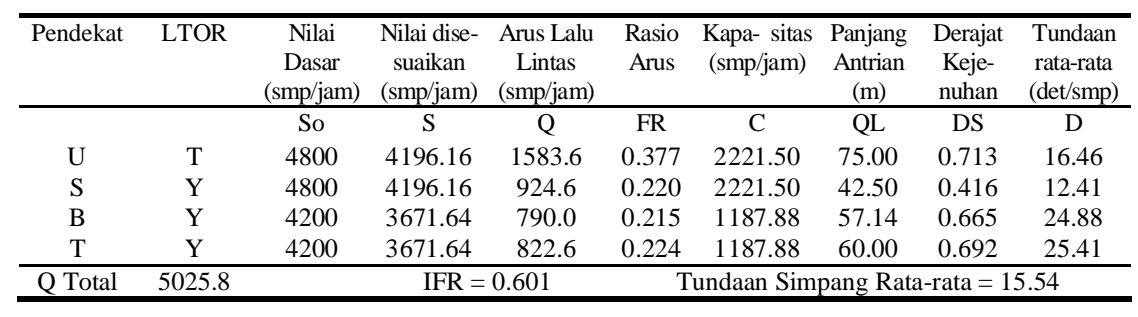

b. Simulasi x pada simpang empat bersinyal $\mathrm{Jl}$. Galunggung $-\mathrm{Jl}$. Tidar $-\mathrm{Jl}$. Bondowoso, yaitu: mensimulasikan bahwa pergerake ken kendaraan dari pendekat utara ( Jl Galunggung) dan pendekat timur (Jl. Bondowoso) tidak boleh belok kiri langsung, sedangkan pada kedua pendekat lainnya disimulasikan belok kiri langsung (LTOR). Simulasi ini dilakukan setelah diketahui bahwa pada kondisi eksisting dan

46 |Media Teknik Sipil, Volume 9, Nomor 1, Februari 2011: 36 - 49
Tabel 12. Kinerja Simpang Empat Bersinyal Jl. Galunggung - Jl. Tidar - Jl. Bondowoso Pada Simulasi $x$

\begin{tabular}{|c|c|c|c|c|c|c|c|c|c|}
\hline Pendekat & LTOR & $\begin{array}{c}\text { Nilai } \\
\text { Dasar } \\
\text { (smp/jam) }\end{array}$ & $\begin{array}{c}\text { Nilai di - } \\
\text { sesuaikan } \\
\text { (smp/jam) }\end{array}$ & $\begin{array}{c}\text { Arus Lalu } \\
\text { Lintas } \\
\text { (smp/jam) }\end{array}$ & $\begin{array}{l}\text { Rasio } \\
\text { Arus }\end{array}$ & $\begin{array}{c}\text { Kapasitas } \\
\text { (smp/jam) }\end{array}$ & $\begin{array}{c}\text { Panjang } \\
\text { Antrian } \\
(\mathrm{m})\end{array}$ & $\begin{array}{c}\text { Derajat } \\
\text { Keje- } \\
\text { nuhan }\end{array}$ & $\begin{array}{l}\text { Tundaan } \\
\text { rata-rata } \\
\text { (det/smp) }\end{array}$ \\
\hline & & So & $\mathrm{s}$ & $\mathrm{Q}$ & FR & $\mathrm{C}$ & QL & DS & $\mathrm{D}$ \\
\hline $\mathrm{U}$ & $\mathrm{T}$ & 4200 & 3671.64 & 611.1 & 0.17 & 931.61 & 48.57 & 0.66 & 27.75 \\
\hline $\mathrm{s}$ & $\mathrm{Y}$ & 4200 & 3671.64 & 694.4 & 0.19 & 931.61 & 54.29 & 0.75 & 30.47 \\
\hline B & $\mathrm{Y}$ & 2880 & 2544.77 & 496.5 & 0.20 & 683.67 & 80 & 0.73 & 30.79 \\
\hline $\mathrm{T}$ & $\mathrm{T}$ & 4200 & 3671.64 & 687 & 0.19 & 986.41 & 62.86 & 0.70 & 28.11 \\
\hline Q Total & 2779.5 & & \multicolumn{2}{|c|}{$\mathrm{IFR}=0.68$} & \multicolumn{5}{|c|}{ Tundaan Simpang Rata-rata $=26.16$} \\
\hline
\end{tabular}

c. Simulasi x pada simpang tiga bersinyal $\mathrm{Jl}$ MT. Haryono - Jl. Gajayana, yaitu: mensimulasikan pergerakan kendaraan dari pendekat selatan (Jl. Gajayana) belok kiri langsung (LTOR) pada fase 1 dan fase 3 , tetapi pada fase 2 semua kendaraan pada pendekat selatan (Jl. Gajayana) haru mengikuti lampu sinyal, termasuk kendaraan yang hendak melakukan pergerakkan belok kiri, sedangkan pada

pendekat barat disimulasikan lurus jalan langsung (StOR) dan pendekat timur disimulasikan belok kiri langsung (LTOR). a dari pendekat timur tidak ada arus pergerakan kendaraan (fase $1 \&$ fase 3 ); dan ketika arus kendaraan dari pendekat timur bergerak (fase 2) maka semua pergerakan kendaraan dari pendekat selatan harus berhenti.

Tabel 13 Kinerja Simpang Tiga Bersinyal Jl. MT. Haryono - Jl. Gajayana Simulasi x

\begin{tabular}{|c|c|c|c|c|c|c|c|c|c|c|}
\hline Pendekat & $\begin{array}{l}\text { LTOR/ } \\
\text { StOR }\end{array}$ & $\begin{array}{c}\text { Lebar } \\
\text { masuk } \\
(\mathrm{m})\end{array}$ & $\begin{array}{c}\text { Nilai } \\
\text { Dasar } \\
\text { (smp/jh) }\end{array}$ & $\begin{array}{c}\text { Nilai di- } \\
\text { sesuaikan } \\
\text { (smp/jh) }\end{array}$ & $\begin{array}{c}\text { Arus Lalu } \\
\text { Lintas } \\
(\mathrm{smp} / \mathrm{j})\end{array}$ & $\begin{array}{l}\text { Rasio } \\
\text { Arus }\end{array}$ & $\begin{array}{c}\text { Kapa- } \\
\text { sitas } \\
\text { (smp/j) }\end{array}$ & $\begin{array}{c}\text { Panjang } \\
\text { Antrian } \\
\text { (m) }\end{array}$ & $\begin{array}{c}\text { Derajat } \\
\text { Keje- } \\
\text { nuhan }\end{array}$ & $\begin{array}{r}\text { Tundaan } \\
\text { rata-rata } \\
\text { (det/smp) }\end{array}$ \\
\hline & & $\mathbf{W}_{\text {entry }}$ & So & $S$ & $\mathbf{Q}$ & FR & C & $\mathbf{Q L}$ & DS & D \\
\hline B & Y & 3,50 & 2100 & 1969,50 & 483,6 & 0,246 & 473,677 & 183,87 & 1,021 & 141,71 \\
\hline $\mathrm{T}$ & Y & 3,00 & 1800 & 1515,65 & 859,5 & 0,567 & 633,12 & 413,33 & 1,358 & 706,90 \\
\hline $\mathrm{S}(\mathrm{RT})$ & Y & 2,50 & 1500 & 1244,18 & 229,8 & 0,185 & 220,49 & 169,28 & 1,042 & 203,12 \\
\hline S (LT) & $\mathrm{Y} / \mathrm{T}$ & 2,00 & 1200 & 928,02 & 593,4 & 0,639 & 552,11 & 524,89 & 1,075 & 202,86 \\
\hline Q Total & 3387 & & & & $\mathrm{IFR}=$ & & Tund & simp & a-rat & $=248,94$ \\
\hline
\end{tabular}

d. Simulasi x pada simpang tiga bersinyal Jl. Letjend Sutoyo - Jl. Sarangan, yaitu: mensimulasikan pergerakan kendaraan dar pendekat utara (Jl. Letjend Sutoyo) diijinkan lurus langsung (StOR) pada pada fase 1 dan fase 2 , sedangkan pada fase 3 semua kendaraan yang melakukan pergerakkan lurus harus mengikuti lampu sinyal lalulintas. Sedangkan pada pendekat barat dan pendekat selatan disimulasikan belok kiri langsung (LTOR). Simulasi in dilakukan dengan pertimbangan (i) sebagai

upaya mengoptimalkan waktu ketika dari pendekat barat tidak ada pergerakan kendaraan belok kanan (fase 1), sedangkan ketika ada pergerakan kendaraan belok kanan (fase 2) volumenya relatif kecil. (ii) pada fase 3 adanya pergerakan kendaraan masuk ke lahan (komersiil) dari pendekat (kimbulkan pergerakan menyilang (crossing) terhadap pergerakan arus kendaraan lurus dari lengan utara, oleh karena itu semua pergerakan kendaraan dari pendekat utara harus berhenti.

Khoirul Abadi ${ }^{1}$,Imam Muryanto ${ }^{2}$,Hermin Eka Wijayanti ${ }^{3}$, Kajian pergerakan kendaraan belok $\mid 47$ kiri langsung Dan lurus langsung pada simpang bersinyal 
Tabel 14. Kinerja Simpang Tiga Bersinyal Jl. Letjend Sutoyo - Jl. Sarangan Simulasi x

\begin{tabular}{|c|c|c|c|c|c|c|c|c|c|c|}
\hline Pendekat & $\begin{array}{l}\text { LTOR/ } / \\
\text { StOR }\end{array}$ & $\begin{array}{c}\text { Lebar } \\
\text { masuk } \\
(\mathrm{m})\end{array}$ & $\begin{array}{c}\text { Nilai } \\
\text { Dasar } \\
\text { (smp/jh) }\end{array}$ & $\begin{array}{l}\text { Nilai di- } \\
\text { sesuaikan } \\
\text { (smp/jh) }\end{array}$ & $\begin{array}{c}\text { Arus Lalu } \\
\text { Lintas } \\
(\mathrm{smp} / \mathrm{j})\end{array}$ & $\begin{array}{l}\text { Rasio } \\
\text { Arus }\end{array}$ & $\begin{array}{c}\text { Kapa- } \\
\text { sitas } \\
\text { (smp/j) }\end{array}$ & $\begin{array}{c}\text { Panjang } \\
\text { Antrian } \\
\text { (m) }\end{array}$ & $\begin{array}{c}\text { Derajat } \\
\text { Keje- } \\
\text { nuhan }\end{array}$ & $\begin{array}{l}\text { Tundaan } \\
\text { rata-rata } \\
\text { (det/smp) }\end{array}$ \\
\hline & & $\mathrm{W}_{\text {entry }}$ & So & $\mathbf{S}$ & $\mathbf{Q}$ & FR & C & QL & DS & D \\
\hline $\mathrm{U}(\mathrm{RT})$ & $\mathrm{T}$ & 3,00 & 1800 & 1556,64 & 114 & 0,07 & 634,19 & 28,68 & 0,180 & 17,79 \\
\hline $\mathrm{S}$ & $\mathrm{T}$ & 7,00 & 4200 & 3472,87 & 1142,1 & 0,33 & 857,50 & 177,14 & 1,332 & 660,53 \\
\hline B & $\mathrm{T}$ & 3,75 & 2250 & 1989,27 & 166,1 & 0,08 & 343,83 & 34 & 0,483 & 34,61 \\
\hline $\mathrm{U}(\mathrm{ST})$ & $\mathrm{Y} / \mathrm{T}$ & 4,00 & 2400 & 2075,52 & 1895,2 & 0,91 & 1358,06 & 310 & 1,396 & 776,05 \\
\hline Q Total & & & 3689 & & $\mathrm{IFR}=1$ & & Tundaan & impan & ta-rata $=$ & 605,29 \\
\hline
\end{tabular}

Secara umum simpang bersinyal pada kondisi eksisting menunjukkan kinerja yang lebih baik dibanding dengan kondisi yang lainnya (simulasi). Hal tersebut dapat dilihat berdasar nilai tundaan simpang rata-rata yang diperoleh, dimana tiga dari empat simpang bersinyal yang ditinjau menunjukkan bahwa kinerja simpang pada kondisi eksisting memiliki nilai terkecil. Demikian pula bila mencermati nilai derajat kejenuhan (DS) maksimum dan panjang antrian (QL) maksimum maksimum dan panjang antrian (QL) maksimum bila mencermati nilai derajat kejenuhan (DS) dan panjang antrian $(\mathrm{QL})$ pada setiap pendekat pada masing-masing simpang, ternyata pada beberapa kondisi simulasi menunjukkan terjadinya perubahan (peningkatan/penurunan) kinerja, perubahan (peningkatan/penurunan) kinerja,
dimana nilai DS dan nilai QL yang diperoleh dimana nilai DS dan nilai QL yang

Dari pembandingan kinerja simpang bersinyal pada beberapa kondisi, cukup jelas bahwa pengaturan pergerakan belok kiri langsung pada pengaturan pergerakan belok kiri langsung pada
simpang empat atau simpang tiga bersinyal, serta simpang empat atau simpang tiga bersinyal, serta
pergerakan lurus langsung pada simpang tiga bersinyal memberi perubahan secara nyata terhadap parameter-parameter kinerja simpang, baik dalam konteks simpang bersinyal itu sendiri maupun pendekat simpangnya.

\section{KESIMPULAN}

Pergerakan kendaraan belok kiri langsung pada simpang empat atau simpang tiga bersinyal, serta pergerakan kendaraan lurus langsung pada simpang tiga bersinyal memberi pengaruh terhadap kinerja simpang bersinyal.
Pengaturan pergerakan belok kiri pad simpang empat atau simpang tiga bersinyal, sert pergerakan lurus pada simpang tiga bersinya sebaiknya dilakukan kajian ilmiah terlebih dahulu. Kajian dilakukan untuk mengetahui pendekatpendekat mana saja yang berpotensi menurunkan pelayanan simpang bersinyal. Sehingga 'kerugian' pengguna simpang akibat tundaan dan ataupun antrian yang akan terjadi dapat dihindari.

\section{DAFTAR PUSTAKA}

Undang Undang Republik Indonesia Nomor 22 Tahun 2009 Tentang Lalu Lintas dan Angkutan Jalan.

Peraturan Pemerintah Nomor 43 Tahun 1993 Tentang Prasarana dan Lalulintas Jalan.

Direktorat Jenderal Bina Marga. 1997. Manual Kapasitas Jalan Indonesia. Jakarta: Departemen Pekerjaan Umum RI.

Oglesby, CH, dan R. Gary Hicks. 1982. Teknik Jalan Raya. Edisi Ke empat Jilid 1. Terjemahan Ir. Purwo Setianto, 1999 Jakarta: Erlangga.

Tamin, O.Z. 1997. Perencanaan dan Pemodelan Transportasi, Penerbit ITB, Bandung

Warpani, Suwardjoko. 2002. Rekayasa Lalu Lintas. Jakarta: Bhratara http://id.wikipedia.org/, Belok Kiri Boleh Langsung. Wikipedia Bahasa Indonesia. (diunduh 28 Oktober 2008) 